\title{
Macro Effect of Corporate Social Responsibility: Based on the Perspective of the High Quality of Economic Growth
}

\author{
Ying DU, Zhixin XUE, Hua YOU \\ Northwest University, Xi'an, China \\ \{Echo2319, xuezhixin0106, hy363\}@163.com
}

\begin{abstract}
This paper interprets the theoretical mechanism of the relationship between corporate social responsibility and the quality of economic growth from micro-perspective, and gives an empirical test of the effect of corporate social responsibility on the quality of economic growth with the data of listed company's corporate social responsibility report rating score from 2010 to 2015. The results show that the improvement of corporate social responsibility will help to promote the development of regional the quality of economic growth. In addition, the corporate social responsibility will have a significant positive impact on the quality of economic growth only in the areas where the proportion of higher education population and tertiary industry accounts for second industry is relatively high and rural-urban income gap is smaller.
\end{abstract}

Keywords: Corporate Social Responsibility, The Quality of Economic Growth, Moderating Effect.

\section{Introduction}

Promoting the quality of micro products and services is the precondition of realizing high quality of macro-economic growth. Enterprises achieve effective operation through improving the quality of products and services, which can promote the transformation of economic development from quantity growth to quality growth and finally realize high quality of economic development at the macro level [1,5]. Therefore, solving quality problems of micro products and services has become the key to mitigating the contradiction between unbalanced and inadequate development and the people's ever-growing needs for a better life, realizing economic modernization, and promoting the development of high quality economy. While the core of improving the quality of products and services is to fulfill corporate social responsibility and consolidate and improve the system of social responsibility.

Therefore, based on the data of corporate social responsibility of listed companies from 2010 to 2015 issued by Hexun net, we make a theoretical and empirical analysis of the effect of corporate social responsibility on the quality of economic growth. The possible marginal contributions of this paper are as follows: Firstly, there is few study on the relationship between corporate social responsibility and the quality of 
economic growth, so the paper links the two of them and interprets the functional mechanism of corporate social responsibility to the quality of economic growth from micro level. Secondly, the impact of corporate social responsibility on the quality of economic growth has not been systematically explained, so this paper systematically analyzes the impact of corporate social responsibility on the quality of economic growth from three dimensions that includes the stability of economic growth, welfare improvement and distribution of fruits and resource utilization and ecosystem cost. Thirdly, since there are differences in the conditions of economic growth in each province, so we introduce three adjustment variables that include the percentage of higher education population, rural-urban income gap and the industrial structure and analyze the influence of these adjustment variables on the relationship between corporate social responsibility and the quality of economic growth.

\section{Literature Review and Hypothesis Development}

\subsection{Corporate Social Responsibility}

Since American scholar Oliver Sheldon formally put forward the concept of corporate social responsibility in 1924, the research on corporate social responsibility has gradually developed in academia. Many scholars have defined corporate social responsibility from different perspectives by using different methods $[4,6,8]$. Among them, the responsibility for shareholders is mainly concerned with enterprise profitability and solvency. The responsibility for employees focuses on caring and safety training for employees. The responsibilities of suppliers, customers and consumers are mainly concerned with products quality and after-sales service. Environmental responsibility is mainly concerned with the input of enterprises in environmental protection and governance. Social responsibility focuses on income tax payment and public donations.

\subsection{The Quality of Economic Growth}

Scholars at home and abroad mainly measure the quality of economic growth from the following two perspectives. Firstly, from a narrow perspective, they think that the quality of economic growth refers to the efficiency of economic growth. Secondly, from a broad perspective, they think that the quality of economic growth belongs to the category of value judgment, which has rich connotation and involves all kinds of aspects of social life [3]. This study uses Chao and Hui's definition of the quality of economic growth, which thinks that the quality of economic growth covers four aspects: the stability of economic growth, the structure of economic growth, the social welfare change and distribution of fruits of economic growth, and resource utilization and ecological environment costs. 


\subsection{Corporate Social Responsibility and the Quality of Economic Growth}

Since reform and opening up, it is obvious that Chinese enterprises have developed fast, but many enterprises have made negative effects on socioeconomic development in the process of rapid expansion, such as production safety risks, lack of employees' rights and interests, violation of consumers' interests and serious environmental pollution, all of which have seriously affected the sustained and healthy development of China's economy [8]. Therefore, when our economy enters a new stage of high quality development, transforming the economic development pattern and enhancing the quality of economic development become the new normal [5], and then the fulfilling of corporate social responsibility has attracted more and more attention [9]. Fulfilling corporate social responsibility is not only concerned about the interests of stakeholder groups but also could promote the welfare of the whole society. Enterprises are required to stick to green development, pay attention to the quality of enterprise development, achieve the maximization of economic and social values, and undertake its own social obligations in the pursuit of profit creation, which has become the common expectation of the government and the public. So, fulfilling corporate social responsibility could standardize enterprise's operation behavior, optimize allocation of resources and ultimately improve the quality of macroeconomic growth by guiding the transformation of enterprises' micro level management mode. Therefore, we pose the following hypothesis:

$\mathrm{H}$ : The fulfillment of corporate social responsibility is conductive to improving the quality of economic growth.

\section{Research Design}

Considering the lagging effect of corporate social responsibility on the quality of economic growth and the superiority of the system GMM in dealing with dynamic panel data (can overcome heteroscedasticity and serial correlation), this paper intends to adopt the system GMM estimation to empirically test the influence of corporate social responsibility on the quality of regional economic growth in China.

\subsection{Model Design}

To test the hypothesis, the following models are constructed:

$$
\begin{aligned}
& \text { economic }_{i t}=\alpha_{0}+\alpha_{1} \text { respo }_{i t}+\alpha_{2} \text { Leconomi }_{i t}+\sum \alpha_{i} * \text { Control }_{i t}+\varepsilon_{i t} \\
& \text { economic }_{i t}=\beta_{0}+\beta_{1}\{\text { share } ; \text { staff } ; \text { welfare } \text { enviro } ; \text { social }\}_{i t} \\
& +\beta_{2} \text { L.economic }_{i t}+\sum_{i} \beta_{i} * \text { Control }_{i t}+\varepsilon
\end{aligned}
$$

Among them, economic $\mathrm{i}_{\mathrm{it}}$ refers to the quality of economic growth. Core independent variables include corporate social responsibility (respo $\left.{ }_{i t}\right)$, shareholder social 
responsibility ( share $\left._{i t}\right)$, employee social responsibility $\left(\right.$ staff $_{i t}$ ), supplier, customer and consumer's rights responsibility (welfare ${ }_{i t}$ ), environment responsibility (enviro ${ }_{i t}$ ), and social responsibility $\left(\right.$ social $\left._{i t}\right)$. L.economicit represents lag phase of the quality of economic growth and Controlit refers to a series of controlled variables that affect the quality of economic growth, consisting of gross fixed assets (assetsit), the elderly dependency dependency ratio (elderly ${ }_{i t}$ ), employment population (employ ${ }_{i t}$ ), government public expenditure ( public $_{i t}$ ), and value of non-state firms (private $\mathrm{it}_{\mathrm{i}}$ ).

\subsection{Sample Selection and Data Sources}

The paper uses social responsibility rating data of A-share listed companies in the Shenzhen and Shanghai stock markets between 2010 and 2015 as the initial research sample and eliminates listed companies labeled as ST and PT, left with 5396 sample observations. Then we take average values of corporate social responsibility rating data by year and province as proxy variable of corporate social responsibility for the province in the year and obtain 180 annual provincial observation values $(30 * 6)$. The remaining data are from China Statistical Yearbook between 2010 and 2016. Variable definitions and instructions are detailed in Table 1.

Table 1. Variable definitions and instructions.

\begin{tabular}{|c|c|c|}
\hline $\begin{array}{l}\text { Variable } \\
\text { symbol }\end{array}$ & Variable name & Variable description \\
\hline economic & $\begin{array}{l}\text { The quality of economic } \\
\text { growth }\end{array}$ & $\begin{array}{l}\text { The index of the quality of economic } \\
\text { growth based on the paper[2] }\end{array}$ \\
\hline haorespo & Corporate social responsibility & $\begin{array}{l}\text { The average values according to year } \\
\text { and province of total score of corporate } \\
\text { social responsibility rating }\end{array}$ \\
\hline share & Shareholder responsibility & $\begin{array}{l}\text { The average values according to year } \\
\text { and province of the score of shareholder } \\
\text { responsibility in the evaluation system }\end{array}$ \\
\hline staff & Employee responsibility & $\begin{array}{l}\text { The average values according to year } \\
\text { and province of the score of employee } \\
\text { responsibility in the evaluation system }\end{array}$ \\
\hline welfare & $\begin{array}{l}\text { Customer and consumer's } \\
\text { rights responsibility }\end{array}$ & $\begin{array}{l}\text { The average values according to year } \\
\text { and province of the score of supplier, } \\
\text { customer and consumer's rights } \\
\text { responsibility in the evaluation system }\end{array}$ \\
\hline
\end{tabular}




\begin{tabular}{|c|c|c|}
\hline enviro & Environmental responsibility & $\begin{array}{l}\text { and province of the score of } \\
\text { environmental responsibility in the } \\
\text { evaluation system }\end{array}$ \\
\hline social & Social responsibility & $\begin{array}{l}\text { The average values according to year } \\
\text { and province of the score of social } \\
\text { responsibility in the evaluation system }\end{array}$ \\
\hline assets & Gross fixed assets & Gross fixed assets in each province/GDP \\
\hline elderly & The elderly dependency ratio & $\begin{array}{l}\text { Elderly population in each } \\
\text { province/working adult population in } \\
\text { each province }\end{array}$ \\
\hline employ & Employment population & Employed persons in each province \\
\hline public & $\begin{array}{l}\text { Government public } \\
\text { expenditure }\end{array}$ & $\begin{array}{l}\text { Government public expenditure in } \\
\text { province/GDP }\end{array}$ \\
\hline private & Value of non-state firms & Value of non-state firms/GDP \\
\hline higher & $\begin{array}{l}\text { The higher education } \\
\text { population }\end{array}$ & $\begin{array}{l}\text { The higher education population in each } \\
\text { province /China's total population }\end{array}$ \\
\hline income & Urban-rural income ratio & $\begin{array}{l}\text { Disposal income of urban residents in } \\
\text { each province/rural net incomes in each } \\
\text { province }\end{array}$ \\
\hline structure & Industrial structure & $\begin{array}{l}\text { The proportion of tertiary industry } \\
\text { output value of second industry output } \\
\text { value in each province }\end{array}$ \\
\hline
\end{tabular}

\section{Empirical Results}

\subsection{Regression Results of Corporate Social Responsibility and the Quality of Economic Growth in Total Samples}

Regression results based on System GMM are shown in Table 2. It can be seen from Table 2 that the relationship between corporate social responsibility and the quality of economic growth is positively related in the $1 \%$ significance level, indicating that corporate social responsibility has a significant positive effect on the quality of regional economic growth. The empirical results also reveal a path mechanism for improving the quality of regional economic growth from micro-enterprise level. Shareholder responsibility is negatively related to the quality of economic growth, while employee responsibility, supplier, customer and consumer rights responsibility, and environmental responsibility are positively related to the quality of economic growth in the $1 \%$ significance level respectively, indicating that if enterprises only 
consider maximizing shareholder's interests will have a negative impact on the quality of regional economic growth. These findings also reflect that the traditional financial management targets - maximization of the profit and the shareholder's wealth can no longer meet the requirements of improving the quality of economic growth at the present stage of China. As an economic organization, enterprises should also actively undertake social responsibility and pay attention to the interests of the internal and external stakeholders while pursuing economic benefits. Among other control variables, gross fixed assets is negatively related to the quality of economic growth in the $1 \%$ level of significant, indicating that excessive investment in fixed assets will lead to waste of resources, produce high energy costs, and reduce the quality of economic growth. The positive effect of value of non-state firms on the quality of economic growth passes a $1 \%$ significant level test, which may be because the investment activities of private enterprises are more complying with market mechanism and more conducive to the improvement of the quality of regional economic growth.

Table 2. Regression results of corporate social responsibility and the quality of economic growth in total samples SYS GMM).

\begin{tabular}{|c|c|c|c|c|c|c|}
\hline $\begin{array}{l}\text { Independent } \\
\text { variables }\end{array}$ & $\begin{array}{l}\text { model (1 } \\
\text { ) }\end{array}$ & $\begin{array}{l}\text { model }(2 \\
)\end{array}$ & $\begin{array}{l}\text { model }(2 \\
)\end{array}$ & $\begin{array}{l}\text { model } \\
(2)\end{array}$ & $\begin{array}{l}\text { model } \\
(2)\end{array}$ & $\begin{array}{l}\text { model } \\
(2)\end{array}$ \\
\hline L1.economic & $\begin{array}{c}0.9556^{* * *} \\
(57.77)\end{array}$ & $\begin{array}{c}0.9543 * * * \\
(69.26)\end{array}$ & $\begin{array}{c}0.9550 * * * \\
(60.29)\end{array}$ & $\begin{array}{c}0.9616^{* * *} \\
(63.30)\end{array}$ & $\begin{array}{c}0.9503 * * * \\
(60.10)\end{array}$ & $\begin{array}{c}0.9504 * * * \\
(64.64)\end{array}$ \\
\hline respo & $\begin{array}{c}0.0061^{* * *} \\
(2.70)\end{array}$ & & & & & \\
\hline share & & $\begin{array}{r}-0.0076 \\
(-0.88)\end{array}$ & & & & \\
\hline staff & & & $\begin{array}{c}0.0285^{* * *} \\
(3.24)\end{array}$ & & & \\
\hline welfare & & & & $\begin{array}{c}0.0212^{* * *} \\
(3.02)\end{array}$ & & \\
\hline
\end{tabular}




\begin{tabular}{|c|c|c|c|c|c|c|}
\hline enviro & & & & & $0.0135^{* *}$ & \\
\hline social & & & & & & $\begin{array}{r}-0.0044 \\
(-1.04)\end{array}$ \\
\hline assets & $\begin{array}{c}-0.0042 * * * \\
(-5.29)\end{array}$ & $\begin{array}{c}-0.0042 * * * \\
(-6.04)\end{array}$ & $\begin{array}{c}-0.0038^{* * * *} \\
(-5.18)\end{array}$ & $\begin{array}{c}-0.0039 * * * \\
(-5.30)\end{array}$ & $\begin{array}{c}-0.0039^{* * * *} \\
(-4.93)\end{array}$ & $\begin{array}{c}-0.0043^{* * *} \\
(-5.08)\end{array}$ \\
\hline elderly & $\begin{array}{r}0.0070 \\
(0.87)\end{array}$ & $\begin{array}{r}0.0028 \\
(0.43)\end{array}$ & $\begin{array}{r}0.0079 \\
(1.02)\end{array}$ & $\begin{array}{r}0.0037 \\
(0.44)\end{array}$ & $\begin{array}{r}0.0066 \\
(0.88)\end{array}$ & $\begin{array}{r}0.0042 \\
(0.62)\end{array}$ \\
\hline employ & $\begin{array}{r}-0.00001 \\
(-0.94)\end{array}$ & $\begin{array}{c}-5.77 \mathrm{e}-06 \\
(-0.30)\end{array}$ & $\begin{array}{r}-0.00002 \\
(-1.23)\end{array}$ & $\begin{array}{r}-0.00003 \\
(-1.39)\end{array}$ & $\begin{array}{r}-0.00001 \\
(-0.68)\end{array}$ & $\begin{array}{c}-1.19 \mathrm{e}-06 \\
(-0.06)\end{array}$ \\
\hline public & $\begin{array}{r}-0.0066 \\
(-1.24)\end{array}$ & $\begin{array}{r}-0.0072 * \\
(-1.85)\end{array}$ & $\begin{array}{r}-0.0084 * \\
(-1.73)\end{array}$ & $\begin{array}{r}-0.0042 \\
(-0.82)\end{array}$ & $\begin{array}{r}-0.0085^{*} \\
(-1.70)\end{array}$ & $\begin{array}{c}-0.0092 * \\
(-1.87)\end{array}$ \\
\hline private & $\begin{array}{c}0.5280^{* * *} \\
(3.28)\end{array}$ & $\begin{array}{c}0.5952^{* * *} \\
(3.99)\end{array}$ & $\begin{array}{c}0.5220^{* * *} \\
(4.11)\end{array}$ & $\begin{array}{c}0.5936^{* * *} \\
(3.59)\end{array}$ & $\begin{array}{c}0.5121^{* * *} \\
(3.86)\end{array}$ & $\begin{array}{c}0.5265^{* * *} \\
(3.56)\end{array}$ \\
\hline _cons & $\begin{array}{r}0.0033 \\
\quad(0.02)\end{array}$ & $\begin{array}{r}0.2669^{*} \\
(1.82)\end{array}$ & $\begin{array}{r}0.0877 \\
(0.55)\end{array}$ & $\begin{array}{r}0.0745 \\
(0.43)\end{array}$ & $\begin{array}{r}0.1631 \\
(1.10)\end{array}$ & $\begin{array}{r}0.2584 \\
\quad(1.56)\end{array}$ \\
\hline$A R(2)$ & $\begin{array}{r}-1.5339 \\
(0.1251)\end{array}$ & $\begin{array}{r}-1.6227 \\
\quad(0.1047)\end{array}$ & $\begin{array}{r}-1.5449 \\
(0.1224)\end{array}$ & $\begin{array}{r}-1.5621 \\
\quad(0.1183)\end{array}$ & $\begin{array}{r}-1.5435 \\
\quad(0.1227)\end{array}$ & $\begin{array}{l}-1.6258 \\
\quad(0.1040)\end{array}$ \\
\hline sargan & $\begin{array}{l}18.2040 \quad(0 \\
.1499)\end{array}$ & $\begin{array}{l}22.3519 \\
\quad(0.0501)\end{array}$ & $\begin{array}{r}18.4889 \\
(0.1398)\end{array}$ & $\begin{array}{l}18.3170 \\
(0.1458)\end{array}$ & $\begin{array}{l}19.2237 \\
(0.1163)\end{array}$ & $\begin{array}{l}22.2142 \\
\quad(0.0521)\end{array}$ \\
\hline
\end{tabular}


Notes: Data is calculated by Stata14.0. z-values is in parentheses.

$* * *, * *, *$ significant respectively at 1 percent, 5 percent, 10 percent level.

\subsection{Further Discussion}

The percentage of population with higher education, urban-rural income ratio and industrial structure has an important effect on the quality of economic growth. Therefore, according to the median value of percentage of population with higher education, urban-rural income ratio and industrial structure between 2010 and 2015, we divide total sample into six sub-sample, including areas with higher percentage of higher education population, areas with lower percentage of higher education population, areas with larger urban-rural income ratio, areas with smaller urban-rural income ratio, areas with higher proportion of tertiary industry in second industry and areas with lower proportion of tertiary industry in second industry.

According to Table 3, in different years, the quality of economic growth in areas with higher percentage of higher education population is obviously better than that in areas with lower percentage of higher education population. We can see that the average values of the quality of economic growth in regions with lower percentage of higher education population are negative from 2010 to 2012 and 2015, while the average values of the quality of economic growth in regions with higher percentage of higher education population are positive in years between 2010 and 2015. the quality of economic growth in regions with smaller urban-rural income ratio are clearly much better than that in regions with larger urban-rural income ratio in different years. The average values of the quality of economic growth in regions with smaller urban-rural income ratio are more than 1 , while those in regions with larger urban-rural income ratio are negative. Moreover, compared to regions with lower proportion of tertiary industry in second industry, the quality of economic growth is significantly better in each year between 2010 and 2015. From 2010 to 2014, the quality of economic growth in areas with lower proportion of tertiary industry in second industry is negative, and that are positive in areas with higher proportion of tertiary industry in second industry.

Table 3. Vertical grouped comparison of the quality of economic growth.

\begin{tabular}{lllllll}
\hline & Lower & Higher & Smaller & Larger & $\begin{array}{l}\text { Lower } \\
\text { proportion }\end{array}$ & $\begin{array}{l}\text { Higher } \\
\text { proportion }\end{array}$ \\
group & percentage & percentage & urban- & urban- & $\begin{array}{l}\text { of tertiary } \\
\text { of tertiary }\end{array}$ \\
year & of higher & of higher & rural & rural & industry in & industry in \\
& education & education & income & income & second & second \\
& population & population & ratio & ratio & industry & industry \\
\hline
\end{tabular}




\begin{tabular}{lllllll}
\hline & $\begin{array}{l}\text { economic } \\
\text { mean }\end{array}$ & $\begin{array}{l}\text { economic } \\
\text { mean }\end{array}$ & $\begin{array}{l}\text { economic } \\
\text { mean }\end{array}$ & $\begin{array}{l}\text { economic } \\
\text { mean }\end{array}$ & $\begin{array}{l}\text { economic } \\
\text { mean }\end{array}$ & $\begin{array}{l}\text { economic } \\
\text { mean }\end{array}$ \\
2010 & -0.0226 & 0.5102 & 1.5705 & -0.4516 & -0.3035 & 1.0720 \\
2011 & -0.4406 & 1.4376 & 1.7329 & -0.4004 & -0.3612 & 1.6546 \\
2012 & -0.1304 & 1.6221 & 1.5109 & -0.3546 & -0.2285 & 1.4772 \\
2013 & 0.0718 & 1.0953 & 1.2808 & -0.4623 & -0.1056 & 1.3712 \\
2015 & 0.1543 & 1.0144 & 1.2865 & -0.3939 & -0.0723 & 1.1003 \\
\hline
\end{tabular}

Notes: Data is calculated by Stata14.0.

Further, we still, by using system GMM, test the relationship between corporate social responsibility and the quality of economic growth through sub-samples regression analysis, on the basis of different sub-samples divided by the percentage of higher education population, the size of urban-rural income gap and the proportion of tertiary industry in second industry. According to Table 4, corporate social responsibility has no significant impact on the quality of economic growth in regions with lower percentage of higher education population, while corporate social responsibility has a positive impact on the quality of economic growth in the $1 \%$ level of significance at regions with higher percentage of higher education population. At the same time, the positive correlation between corporate social responsibility and the quality of economic passes a $1 \%$ significant level test in regions with smaller urban-rural income gap, but there is no significant effect of corporate social responsibility on the quality of economic growth in regions with larger urban-rural income gap. In areas with lower proportion of tertiary industry in second industry, corporate social responsibility has a negative but not significant impact on the quality of economic growth, the positive impact of corporate social responsibility on the quality of economic growth passes a 1\% significant level test in areas with higher proportion of tertiary industry in second industry. The results show that the percentage of higher education population, the urban-rural income gap and the proportion of tertiary industry in second industry have a regulating effect on the relationship between corporate social responsibility and the quality of economic growth. The positive impact of corporate social responsibility on the quality of economic growth can only be significantly released in areas with higher percentage of the higher education population, smaller urban-rural income gap and higher proportion of tertiary industry in second industry. 
Table 4. Regression results of corporate social responsibility and the quality of economic growth in sub-samples (SYS GMM).

\begin{tabular}{|c|c|c|c|c|c|c|}
\hline $\begin{array}{l}\text { Independent } \\
\text { variables }\end{array}$ & $\begin{array}{l}\text { Lower } \\
\text { percentage } \\
\text { of higher } \\
\text { education } \\
\text { population } \\
\text { model (1) }\end{array}$ & $\begin{array}{l}\text { Higher } \\
\text { percentage } \\
\text { of higher } \\
\text { education } \\
\text { population } \\
\text { model (1) }\end{array}$ & $\begin{array}{l}\text { Smaller } \\
\text { urban-rural } \\
\text { income ratio } \\
\text { model (1) }\end{array}$ & $\begin{array}{l}\text { Larger } \\
\text { urban-rural } \\
\text { income } \\
\text { ratio } \\
\text { model (1) }\end{array}$ & $\begin{array}{l}\text { Lower } \\
\text { proportion } \\
\text { of tertiary } \\
\text { industry in } \\
\text { second } \\
\text { industry } \\
\text { model (1) }\end{array}$ & $\begin{array}{l}\text { Higher } \\
\text { proportion } \\
\text { of tertiary } \\
\text { industry in } \\
\text { second } \\
\text { industry } \\
\text { model (1) }\end{array}$ \\
\hline L.economic & $\begin{array}{c}0.8202 * * * \\
(18.72)\end{array}$ & $\begin{array}{c}0.9508 * * * \\
(82.15)\end{array}$ & $\begin{array}{c}0.9417 * * * \\
(93.17)\end{array}$ & $\begin{array}{c}0.7635^{* * *} \\
(10.28)\end{array}$ & $\begin{array}{c}0.8433 * * * \\
(14.82)\end{array}$ & $\begin{array}{c}0.9024 * * * \\
(52.97)\end{array}$ \\
\hline respo & $\begin{array}{c}-0.0008 \\
(-0.76)\end{array}$ & $\begin{array}{c}0.0126^{* * *} \\
(2.79)\end{array}$ & $\begin{array}{c}0.0066^{* * *} \\
(4.72)\end{array}$ & $\begin{array}{r}-0.0008 \\
(-0.48)\end{array}$ & $\begin{array}{r}0.0010 \\
(0.29)\end{array}$ & $\begin{array}{c}0.0080^{* * *} \\
(4.59)\end{array}$ \\
\hline assets & $\begin{array}{c}-0.0020^{*} \\
(-1.83)\end{array}$ & $\begin{array}{c}-0.0055^{* * *} \\
(-4.00)\end{array}$ & $\begin{array}{c}-0.0092 * * * \\
(-2.28)\end{array}$ & $\begin{array}{c}-0.0016^{* * *} \\
(-3.58)\end{array}$ & $\begin{array}{r}0.00009 \\
(0.12)\end{array}$ & $\begin{array}{c}-0.0102 * * * \\
(-8.79)\end{array}$ \\
\hline elderly & $\begin{array}{l}0.0549^{* * *} \\
\quad(9.90)\end{array}$ & $\begin{array}{c}-0.0201 * * * \\
(-3.22)\end{array}$ & $\begin{array}{l}0.0028 \\
(0.38)\end{array}$ & $\begin{array}{c}0.0154 * * \\
(2.34)\end{array}$ & $\begin{array}{c}0.0425^{* * *} \\
\quad(5.64)\end{array}$ & $\begin{array}{r}0.0012 \\
(0.13)\end{array}$ \\
\hline employ & $\begin{array}{c}1.32 \mathrm{e}-06 \\
(0.05)\end{array}$ & $\begin{array}{c}-0.00004^{* *} \\
(-2.46)\end{array}$ & $\begin{array}{c}-0.00005^{* * * *} \\
(-4.98)\end{array}$ & $\begin{array}{r}0.00003 \\
(0.84)\end{array}$ & $\begin{array}{c}-3.25 \mathrm{e}-06 \\
(-0.10)\end{array}$ & $\begin{array}{c}0.00006 \\
(1.46)\end{array}$ \\
\hline public & $\begin{array}{c}-0.0095 * * * \\
(-5.10)\end{array}$ & $\begin{array}{c}-0.0057 \\
(-0.92)\end{array}$ & $\begin{array}{c}-0.0065 \\
(-1.06)\end{array}$ & $\begin{array}{r}0.0047 \\
(1.13)\end{array}$ & $\begin{array}{r}-0.0037 \\
(-1.13)\end{array}$ & $\begin{array}{r}-0.0050 \\
(-1.09)\end{array}$ \\
\hline private & $\begin{array}{c}-0.0232 \\
(-0.11)\end{array}$ & $\begin{array}{r}0.5244^{*} \\
(1.94)\end{array}$ & $\begin{array}{r}0.2662 \\
(1.57)\end{array}$ & $\begin{array}{c}0.5789 * * * \\
(5.39)\end{array}$ & $\begin{array}{r}-0.2134 \\
(-0.92)\end{array}$ & $\begin{array}{c}1.0958^{* * *} \\
(-2.15)\end{array}$ \\
\hline _con & $\begin{array}{r}-0.2394 \\
(-1.22)\end{array}$ & $\begin{array}{c}0.3769 \\
(1.12)\end{array}$ & $\begin{array}{c}0.6339 * * \\
(2.53)\end{array}$ & $\begin{array}{c}-0.6054^{* *} \\
(-2.34)\end{array}$ & $\begin{array}{r}-0.2644 \\
(-1.32)\end{array}$ & $\begin{array}{c}-0.3654^{* *} \\
(-2.15)\end{array}$ \\
\hline $\mathrm{AR}(2)$ & & $\begin{array}{l}-1.2514 \\
(0.2108)\end{array}$ & & $\begin{array}{r}-0.0327 \\
(0.9739)\end{array}$ & & $\begin{array}{l}-1.2236 \\
(0.2211)\end{array}$ \\
\hline sargan & & $\begin{array}{l}14.3135 \\
(0.3521)\end{array}$ & & $\begin{array}{l}11.7913 \\
(0.5448)\end{array}$ & & $\begin{array}{l}19.0644 \\
(0.1211)\end{array}$ \\
\hline $\mathrm{N}$ & 70 & 80 & 81 & 69 & 70 & 80 \\
\hline
\end{tabular}

Notes: z-values in parentheses.

$* * * \mathrm{p}<0.01, * * \mathrm{P}<0.05, * \mathrm{p}<0.1$.

\section{Conclusion}

The relationship between corporate social responsibility and the quality of economic growth involves a major problem of building a realistic channel of improving the quality of economic growth. The results are as follow: Firstly, there is a positive 
relationship between corporate social responsibility and the quality of economic growth. With the improvement of corporate social responsibility, the quality of economic growth also increases. Among them, shareholder responsibility has an negative effect on the quality of economic growth, while the improvement of employee responsibility, suppliers, customers and consumer's rights responsibility will enhance the quality of economic growth. Secondly, corporate social responsibility has a significant positive impact on the quality of economic growth in areas with higher percentage of higher education population, smaller urban-rural income gap or higher proportion of tertiary industry in second industry, which means that human capital, income distribution and industrial structure have a regulating effect on the relationship between corporate social responsibility and the quality of economic growth. Fourthly, among other controlled variables, the over-investment of fixed assets is not conducive to sustainable high economic growth, while the development of private enterprises could improve the quality of economic growth.

Nowadays, China is in the critical stage of changing the mode of economic development. In order to solve the contradiction between the growing needs of our people and the state of unbalanced and inadequately development, we must firmly promote high quality development and realize economic development from the expansion of quantity to the improvement of quality. Based on this, this paper puts forward the following policy suggestions: (1) We find that corporate social responsibility has a significant positive effect on the quality of economic growth, which shows a micro path of improving the quality of economic growth, fulfilling corporate social responsibility. (2) Considering the fact that the current financial management goal of "maximizing profit and shareholder wealth" could not meet the requirements of high quality economic development in the new era of China, enterprises needs to establish a management mechanism of altruistic symbiosis and pay more attention to corporate social responsibility, especially employee responsibility, supplier, customer and consumer rights responsibility and environmental responsibility, which will provide positive contribution to the improvement of Chinese economic through the healthy development of enterprises. (3) Human capital, income distribution and industrial structure have a regulating effect on the relationship between corporate social responsibility and the quality of economic growth. The higher percentage of higher education population, the smaller urban-rural income gap and the higher proportion of third industry in second industry are conducive to the formation of positive incentives between the corporate social responsibility and the quality of economic growth. Therefore, expanding the accumulation of human capital, narrowing the income distribution gap and adjusting the industrial structure are still important channels of achieving high quality of economic growth in the new era. 


\section{References}

1. Chao, X. J., Ren, B.P., Xu, L.: Regional Disparity of the Quality of China's Economic Growth: Based on the Test of the Semi-Parametric Model for Heterogeneity over Time and across Individuals (in Chinese). Journal of Jiangxi university of finance \& economics 1, 10-20 (2016). DOI: 10.13676/j.cnki.cn36-1224/f.2016.01.002.

2. Chao, X. J., Ren, B.P.: The Fluctuation and Regional Difference of Quality of Economic Growth in China (in Chinese). Economic research 46(4), 26-40 (2011).

3. Chao, X. J., Hui K.: Measuring Quality of Economic Growth of China (in Chinese). The journal of quantitative and technical economics 6, 75-86 (2009). DOI: 10.13653/j.cnki.jqte.2009.06.008.

4. Huang, J. B., Xu, J., Xu, S.: Land Price Distortion Enterprises' Property and Over investment: An Empirical Research Based on the Data of Chinese Industrial Enterprises and Land Price of Cities in China (in Chinese). China industry economic 3, 57-69 (2015). DOI: 10.19581/j.cnki.ciejournal.2015.03.005.

5. Ren, B. P., Gan, H.X.: Construction the Micro Mechanism of Improving Chinese Quality of Economic Growth (in Chinese). Guizhou social science 5, 111-118 (2016). DOI: 10.13713/j.cnki.cssci.2016.05.019.

6. Wang, S. H.: A Study of the Influence of Management Background Characteristics on Corporate Social Responsibility: Empirical Evidence from Chinese A-share Listed Companies (in Chinese). Accounting research 11, 53-60+96 (2016).

7. Xiao, H. J., Li, W.Y., Hu, Y.L.: True or False Proposition: A New Thinking about the Testing of CSR (in Chinese). China industry economic 2, 102-114 (2015). DOI: 10.19581/j.cnki.ciejournal.2015.02.010.

8. Xu, S., Huang, J.B.: Media Governance and Corporate Social Responsibility (in Chinese). Chinese journal of management 7, 1072-1081 (2015).

9. Xu, Z. L., Liu, N.: Research on Management Integration of CSR and Corporate Strategic Objective Based on Sustainable Development (in Chinese). China industry economic 9, 129-140 (2008). DOI: 10.19581/j.cnki.ciejournal.2008.09.013. 